\title{
PROSES BELAJAR: TANTANGAN DALAM PENELITIAN BIDANG PEMBANGUNAN PENDIDIKAN MASYARAKAT
}

Oleh : Djoko Susanto*

\section{Abstrak}

Menyimak dari negara-negara maju di mana penghasilan penduduknya per kapita setahun relatif tinggi dan kualitas SDMnya juga tinggi, maka terbukti bahwa keberhasilan seperti itu diakibatkan terutama oleh proses belajar yang intensif, berkualitas dan mendapat prioritas dan dana besar, baik dari pemerintah maupun masyarakat di negara-negara bersangkutan.

Di negara-negara tersebut 'belajar' telah menjadi kebutuhan masyarakat sehari-hari, bahkan seolah-olah sebagian besar masyarakat tidak mau ketinggalan untuk belajar menyimak berbagai informasi metalui media massa cetak dan elektronik. Membaca merupakan budaya sekaligus sebagai sumber belajar bagi sebagian besar orang di negara yang sudah maju seperti: Jepang, Korea Selatan, Singapore dan lainnya. Mengapa semangat belajar yang tinggi dan positif seperti di negara-egara maju tersebut relatif lambat, kalau tidak ingin dikatakan 'belum merambah' pada sebagian besar masyarakat kita? Dalam tulisan ini, penulis ingin menyampaikan satu pemikiran ke arah itu dan mencoba mengkaji di mana sesungguhnya penelitian bidang pendidikan masyarakat dapat turut berkiprah untuk memperbaiki dan meningkatkan kualitas program pendidikan masyarakat, dan pada gilirannya meningkatkan kualitas sumber daya manusia dan martabat serta harga diri masyarakat.

*) Prof. (RIS) Dr. Djoko Susanto, SKM, APU, adalah Peneliti Badan Litbang Kesehatan, Dosen Pasca Sarjana IPB 


\section{A. PENDAHULUAN}

Seperfi dikemukakan oleh Adler (1989) : 'Tujuan dari proses belajar adalah pertumbuhan, tidak seperti tubuh kita maka pikiran kita dapat tumbuh terus selama hayat dikandung badan (' $T h e$ purpose of learning is growth, unlike our bodies our minds can continue growing as we continue to live'). Dengan kata-kata lain: pada dasarnya setiap individu setiap saat memiliki peluang untuk 'belajar'. Di sini pengertian 'belajar' bisa berarti 'belajar apa saja', artinya proses belajar tidak senantiasa harus berlangsung tatkala seseorang duduk di bangku sekolah atau di bangku kuliah, melainkan di mana saja ia berada. Sebagai contoh: tatkala seseorang berada di dalam kendaraan umum, ia perlu belajar untuk tidak merokok (ini berlaku bagi individu yang biasa merokok); seorang pemimpin perlu 'belajar menyapa' bawahannya tatkala ia tiba di kantor, atau jika ada stafnya yang datang ke kamar kerjanya.

Sebagai makhluk sosial, seseorang sejak lahir sudah dilengkapi dengan sarana (baca: naluri) untuk 'belajar'. Contohnya: seorang jabang bayi sehat yang baru keluar dari rahim ibunya pasti menangis. la mulai belajar untuk minta perhatian agar kehadirannya di dunia ini mendapat pengakuan dari orang-orang yang berada di sekitarnya. Jika bayi itu segera dipegang dan diselimuti dengan kasih-sayang maka ia akan segera berhenti menangis. Pengakuan bagi setiap orang acapkali merupakan 'harga yang mahal' karena menjadi bagian terpenting dari kebutuhannya untuk tetap eksis di dunia ini. Secara teori dan empirik: sejak seseorang lahir dan sepanjang hidupnya maka ia senantiasa terdorong untuk belajar memenuhi kebutuhan-kebutuhannya melalui berbagai cara.

Pada dasarnya, setiap orang berperilaku tertentu untuk memenuhi kebutuhan-kebutuhannya yang majemuk. Mengambil istilah yang dikemukakan oleh Sen (1982): setiap orang 'berhak' atau 'entitled' untuk belajar. Namun pada kenyataannya walaupun peluang untuk belajar itu (belajar apa saja!) terbuka, tidak semua orang terdorong untuk memanfaatkan peluang tersebut karena beragam sebab. Artinya 'belajar 
belum menjadi kebutuhan yang penting dalam kalangan masyarakat kita.

'Lahan' pembangunan bidang pendidikan masyarakat masih sangat terbuka luas untuk digarap, khususnya bagi para peneliti dan pemerhati dalam bidang ini. Salah satu indikator yang menunjukkan luasnya 'lahan garapan' itu adalah masih banyaknya masalah sosial dalam masyarakat yang terkait dengan perilaku individu-individu yang tergolong menyimpang (deviant behavior) dari tatanan normatif dan manusiawi. Perilaku-perilaku menyimpang yang bersifat negatif itu secara naif dapat dikaitkan dengan pertanyaan berikut: 'Mengapa orang kok tidak mudah untuk belajar berperilaku positif?' Sebaliknya: dari sudut pandang positif, kita dapat mengajukan pertanyaan ini 'Indikator apa yang dapat ditetapkan sebagai baku atau tolok ukur dan menjadi tatanan sosial (social rule menurut Popenoe,1989) untuk berperilaku positif, normatif dan manusiawi?'

Penelitian dalam bidang pembangunan pendidikan masyarakat sebagai bagian penting di dalam upaya meningkatkan program pendidikan yang bermuara pada peningkatan kualitas sumber daya manusia perlu dikembangkan sedemikian rupa, sehingga dapat dihasilkan temuan-temuan penting berikut dalam masyarakat, yakni:

1. Kesenjangan antara perilaku kini, aktual dan faktual yang ada dalam sistem sosial masyarakat dengan perilaku normatif, manusiawi seperti diharapkan; kesenjangan ini identik dengan masalah yang dihadapi oleh program pembangunan bidang pendidikan masyarakat;

2. Selain kompetensi dan prestasi belajar, indikator atau tolok ukur apa yang perlu dirumuskan dan ditetapkan sebagai pegangan bagi proses belajar yang berhasil (successful teaming process);

3. Kebutuhan belajar apa yang didambakan atau diharapkan agar masyarakat di berbagai daerah semakin mampu untuk mandiri, kreatif dan bersaing di era globalisasi dan informasi serta mampu mengatasi masalah-masalah yang mereka hadapi; 
4. Kebutuhan belajar apa yang perlu didorong dan disadarkan agar dalam masyarakat di berbagai daerah tumbuh dan berkembang kreativitas untuk menciptakan masyarakat madani (civil society), di mana keterpercayaan sosial (social trust, Fukuyama 1999) menjadi tonggak yang kokoh sebagai modal sosial masyarakat;

5. Pengembangan model-model intervensi terhadap berbagai perilaku menyimpang yang ditemukan dalam masyarakat di berbagai daerah melalui proses belajar agar kondisi negatif itu tidak semakin luas;

6. Sebab-sebab dan akar penyebab dari munculnya masalahmasalah sosial yang terkait dengan perilaku menyimpang;

7. Lingkungan belajar, termasuk lingkungan kebijakan seperti apa yang perlu dikembangkan dalam masyarakat sehingga dorongan belajar dapat tumbuh dan berkembang secara optimal.

\section{B. MENELITI BERDASARKAN FALSAFAH}

Penulis berpreposisi bahwa di dalam bidang pembangunan pendidikan masyarakat terkandung secara implisit berbagai falsafah yang penting sebagai landasan operasional, yang relatif terbanyak dan terintensif dibanding dengan pembangunan bidangbidang lain. Kondisi ini masuk akal karena sasaran utama pembangunan ini adalah 'individu seutuhnya', di mana produk akhir dari berbagai kegiatan proses belajar adalah meningkatnya kualitas SDM sasaran belajar, baik dari sudut pandang pemenuhan kebutuhan biologik, psikologik maupun sosiologik, serta martabat dan harga dirinya. Demikian pula dalam penelitian bidang pendidikan masyarakat terkandung demikian banyak falsafah yang mendukung alasan: mengapa penelitian dalam bidang ini sangat diperlukan.

Falsafah sebagai landasan rasional dari kebenaran tentang pemikiran dan tindakan seseorang di dalam melakukan kegiatan tertentu (termasuk kegiatan penelitian bidang pendidikan 
masyarakat) adalah sarana untuk mendukung keabsahan (legitimasi) dari kegiatan yang perlu dilakukan tersebut Landasan falsafah penting dalam penelitian sosial misalnya: Sesuatu kejadian (evidence) muncul dalam masyarakat bukanlah karena kebetulan, melainkan karena adanya faktor-faktor penyebab. Dalam membahas mengenai falsafah penelitian dapat diajukan pertanyaan-pertanyaan sebagai berikut:

1. Mengapa seseorang sepanjang hidupnya berpeluang, bahkan 'wajib' untuk belajar?

2. Apa tujuan dari belajar?

3. Bagaimana menumbuhkan dan mengembangkan kebutuhan belajar datam masyarakat?

4. Motto mana yang perlu ditumbuh-kembangkan dalam masyarakat:
A. Belajar untuk hidup; atau
B. Hidup untuk belajar; atau
C. Keduanya (A. dan B.)

5. Mengapa lingkungan belajar dan kebijakan pemerintah tentang proses belajar yang kondusif dan positif perlu dikembangkan dan dipelihara bagi keberhasilan proses belajar dalam masyarakat? Dari masing-masing ke-5 contoh di atas, kemudian dapat dikembangkan landasan-landasan pikir yang tertuju pada alasan pentingnya penelitian dalam bidang ini untuk secara sungguh-sungguh dirancang dan diimplementasikan.

Dari contoh 1. misalnya landasan rasionalnya adalah sebagai berikut: Sebagai makhluk sosial yang memiliki akal dan budi setiap individu 'berhak' untuk mengembangkan dirinya dari 'Saya' ('I') sekarang menjadi 'Saya yang baru' ('Me') kelak setelah saya menjalani proses belajar tertentu. Saya 'yang baru' mengandung konotasi: yang berperilaku lebih baik, yang lebih kompeten, lebih baik dan lebih bermartabat serta lebih berkepribadian. Hak itu bagi setiap individu adalah sah-sah saja karena kehadiran seseorang dalam lingkungannya perlu diberi pengakuan (recognition). Ruben (1988), Ausubel, et al. (1978) menyatakan bahwa kepribadian dan prestasi belajar seyogyanya berjalan seiring. Prestasi belajar yang 
rendah pada sasaran didik secara umum berkaitan dengan kemampuan penyesuaian kepribadian yang rendah.

Mengapa penelitian bidang pendidikan masyarakat perlu berlandaskan falsafah? Jawaban normatif adalah agar hasil penelitian bidang ini tidak terkategori sebagai : 'So what research' atau sebagai penelitian yang tidak jelas 'apa manfaatnya', bagi siapa kemaslahatannya dan apa implikasinya bagi pemegang kebijakan. Kepentingan penyelenggaraan penelitian bidang pembangunan pendidikan masyarakat perlu dirumuskan secara jelas dan 'menggigit' agar dapat diterima oleh banyak pihak, khususnya oleh penyandang dana.

\section{PROSES BELAJAR DAN SISTEM NILAI}

Dalam bahasan berikut penulis perlu mendapatkan kesepakatan terlebih dahulu dari pembaca budiman, bahwa penyelenggaraan pendidikan formal, non formal dan informal tiada lain adalah merupakan bentuk-bentuk dari proses belajar.

Dalam teori rangsangan-respon (stimulus-response theory) dari Thorndike (1963) dikatakan, bahwa seseorang 'telah belajar sesuatu' dengan baik jika ia: 'tahu, mau dan mampu memberi reaksi reaksi atau respon yang benar terhadap berbagai rangsangan berasal dari sesuatu tersebut. Teori itu walaupun sudah lama digulirkan oleh Thorndike, tetapi hingga kini terasa masih relevan untuk dijadikan pegangan di dalam bidang pendidikan masyarakat. Sebagai contoh sederhana: seorang lelaki dapat dikatakan 'telah belajar menjadi suami yang baik' jika ia senantiasa tahu, mau dan mampu memberi respon yang benar terhadap berbagai rangsangan (baca: kebutuhan-kebutuhan) dari isterinya.

Dalam rumusan dari teori tersebut yang hampir selalu menjadi bahan perdebatan adalah 'yang benar' seperti apa atau 'yang benar' menurut siapa. Di sini lalu muncul pemikiran perlunya dikaji dan ditumbuh-kembangkan berbagai sistem nilai (value system) positif 
untuk berperilaku sesuai dengan latar belakang sistem budaya lokalita di mana masyarakat berada. Perlu ditemukan berbagai kearifan lokal dan cara-cara masyarakat 'belajar dan berperilaku yang didasarkan pada pola-pola interaksi sosial dalam masyarakat yang dipelajari oleh peneliti.

Sudah bukan menjadi rahasia lagi jika di negara kita, bahkan di negara-negara yang sudah maju sekalipun bahwa tidak setiap individu berusia sekolah memiliki akses untuk mengikuti pendidikan formal karena berbagai alasan. Sementara di sisi lain: tidak setiap sasaran didik yang telah terlibat dalam pendidikan formal dapat mengatakan dengan pasti 'apa tujuan ia bersekolah', atau dorongan apa yang menyebabkan ia bersekolah. Tatanan yang normatif semestinya adalah sebagai berikut: seseorang terlibat dalam proses belajar formal agar setelah selesai menjalani proses belajar itu, ia bisa : belajar lebih lanjut, ia bisa langsung bekerja atau ia bisa langsung menciptakan 'kerja'. Jika kepastian mengenai hal ini suram atau tidak jelas, maka sasaran didik dapat terkurangi dorongan belajarnya dan kondisi seperti itulah yang sedang kita hadapi bersama dewasa ini.

Proses belajar dalam pendidikan formal secara ideal semestinya nyambung dengan 'implikasi proses belajar selanjutnya' atau 'implikasi bekerja sesuai minaY setelah proses belajar berakhir pada setiap sasaran didik. Dengan kata-kata lain: penyelenggara program pendidikan formal di berbagai tingkatan (rendah, menengah dan tinggi) perlu secara arif berkoordinasi dengan pihakpihak terkait dan turut memikirkan kelanjutan dari 'nasib' setiap sasaran didiknya tatkala yang terakhir ini telah berhasil menyelesaikan proses belajar di institusinya.

Pendidikan luar sekolah yang tergolong sebagai pendidikan non formal adalah salah satu bentuk proses belajar yang dapat menampung sasaran-sasaran didik yang putus sekolah dan yang tidak tertampung di institusi pendidikan formal. Dalam proses belajar non formal ini, sasaran didik dapat dibekali pengetahuan dan 
ketrampilan tertentu yang kemudian dapat diarahkan untuk bekerja mandiri atau menciptakan 'kerja' yang langsung atau tidak langsung dapat menghasilkan uang. Sementara proses belajar informal dapat disasarkan kepada siapa saja yang berada di dalam konteks lingkungan keluarga. Indikator keberhasilan proses belajar informal adalah: terciptanya berbagai nilai positif dalam keluarga yang tercermin dari perilaku anggota-anggotanya. Nilai-nilai positif dalam keluarga dapat tumbuh dan berkembang dengan baik, jika (1) terdapat komunikasi yang baik antar anggota keluarga; (2) budaya saling menghargai dan saling memberi pengakuan dalam posisi dan peran masing-masing anggota keluarga ditemukan dalam keluarga; (3 terdapat nuansa saling berbagi pengalaman, keceriaan dan kepedihan antar anggota keluarga; (4) adanya sikap dan rasa yang positif dalam hal saling mempercayai dan keterbukaan antar anggota keluarga. Melalui penumbuh-kembangan nilai-nilai yang positif sebagai landasan perilaku anggota-anggota di tingkat keluarga, maka diharapkan sistem nilai ini akan mempengaruhi lingkungan di mana keluarga tersebut berada.

\section{PENDEKATAN FENOMENA GUNUNG ES DALAM PENELITIAN PENDIDIKAN}

Penelitian dalam bidang ilmu-ilmu sosial termasuk di sini penelitian bidang pendidikan dapat dilakukan melalui pendekatan 'fenomena gunung es' (ice berg phenomenon). Dalam pendekatan ini dibuat asumsi-asumsi yang rasional sifatnya, sebagai berikut:

Asumsi 1 : Masalah yang ditemukan berkaitan dengan perilaku menyimpang dalam masyarakat kita tempatkan sebagai 'puncak gunung es' yang muncul di 'permukaan dan diketahui oleh masyarakat secara luas sebagai ‘kejadian' (evidence), masalah sosial;

Asumsi 2 : Puncak gunung es muncul karena adanya bongkahan es di bawahnya. Artinya: masalah sasial itu muncul 
karena ada 'penyebab langsung'; di manapun masalah itu ditemukan umumnya penyebab langsungnya adalah sama, sehingga disebut sebagai POLA;

Asumsi 3 : Bongkahan es di bawah puncak gunung es itu ada karena terdapat bongkahan es yang jauh lebih besar dan luas di bawahnya sampai dasar laut. Artinya: penyebab langsung dari masalah sosial itu ada karena terdapat penyebab tidak langsung yang berada dalam sistem sosial dan budaya masyarakat; karenanya akar masalah ini disebut juga sebagai STRUKTUR (pola interaksi sosial);

Asumsi 4 : Jika puncak gunung es tidak diatasi, maka hal itu akan memberi dampak negatif, antara lain dapat menenggelamkan kapal. Artinya: jika masalahmasalah sosial tidak diatasi maka hal ini akan berdampak buruk bagi masa depan bangsa.

Pendekatan fenomena gunungn es dalam penelitian sosial akan lebih mantap jika digabung dengan pendekatan 'pohon masalah' (the problem free) yang ditawarkan oleh D-GTZ (1988) dengan penamaan ZOPP (Ziel Orientierte Projekt Plannung).

Berikut ini disajikan satu contoh pendekatan fenomena gunung es digabung dengan ZOPP: 


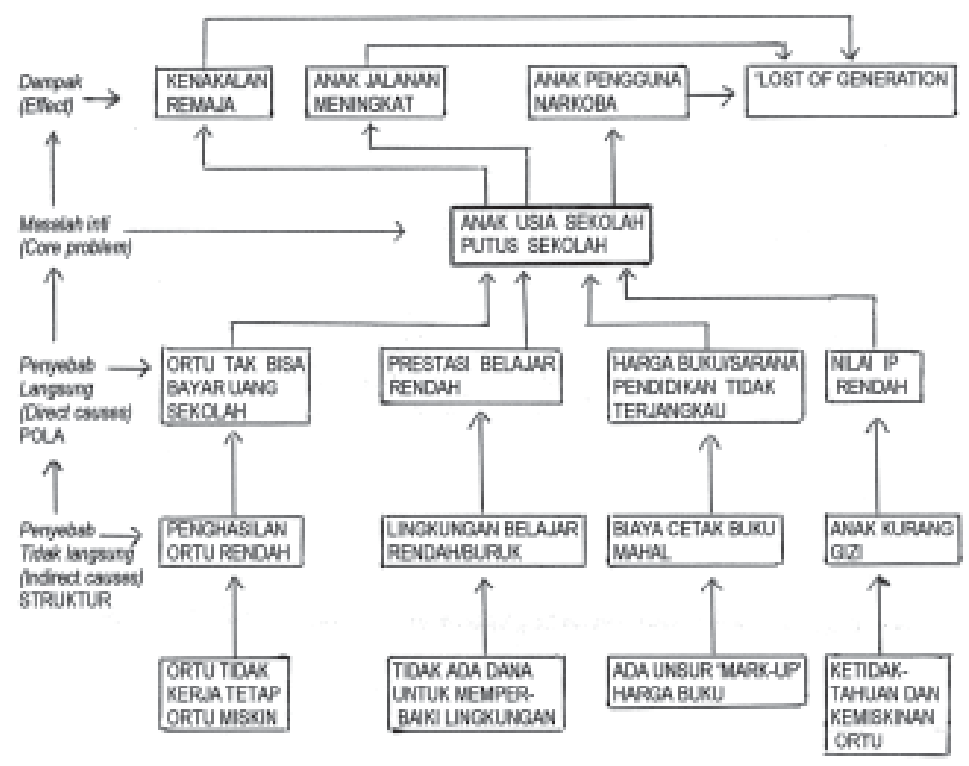

Bagan : 'Pohon masalah' hubungan antara anak putus sekolah dengan penyebab langsung dan penyebab tidak langsung serta dampak masalah

Dari Bagan di atas dapat disimak, bahwa masalah dalam bidang pendidikan amat sangat terkait dengan banyak faktor yang tergolong penyebab langsung dan penyebab tidak langsung. Masalah inti tidak akan serta-merta hilang ketika penyebab langsung dapat diatasi karena masih terdapat penyebab tidak langsung sebagai akar masalah, yang berada di dalam sistem sosial atau struktur masyarakat bersangkutan.

Peneliti dalam bidang pendidikan masyarakat perlu memahami dan mencoba menganalisis dan mencari jawaban atas pertanyaan ini: Mengapa dalam masyarakat ditemukan demikian banyak anakanak usia sekolah yang tidak bersekolah, mereka lebih suka berada di jalanan atau melakukan hal-hal yang kontra produktif? Apa dampak masalah itu bagi masyarakat? 
Jawaban atas pertanyaan seperti di atas dapat mengundang peneliti untuk mengembangkan rencana penelitian guna mendapatkan pemecahan di dalam masalah pendidikan masyarakat. Selain untuk mendapatkan jawaban atas pertanyaan 'Mengapa' juga dapat digali lebih mendalam: 'Apa arti pendidikan dan proses belajar bagi mereka, serta 'Apa kebutuhan belajar mereka'.

Bagan 'pohon masalah' (problem tree) dapat dijadikan sarana bagi peneliti untuk mengembangkan cara pikir (mind set) di dalam merancang sesuatu kegiatan penelitian bidang pendidikan. Tergantung dari jumlah dana yang tersedia, maka peneliti dapat secara bebas menetapkan peubah (variable) mana yang akan dijadikan sebagai 'masalah inti' (core problem). Dengan memindah-mindahkan peubah masalah inti maka akan memberi konsekuensi jumlah dana penelitian yang berbeda, bisa lebih kecil atau sebaliknya.

\section{E. KESIMPULAN}

Penelitian dalam bidang pendidikan masyarakat masih sangat terbuka luas antara lain karena sebagian besar masyarakat kita masih berpendidikan rendah, hidup dalam tingkat kesejahteraan yang masih memprihatinkan, serta masih adanya kesenjangan sosial dan ekonomi yang relatif lebar antara sebagian besar penduduk dengan sebagian kecil penduduk yang menguasai berbagai asset dan modal. Penelitian dalam bidang ini diharapkan dapat menghasilkan temuan-temuan penting yang dapat dijadikan landasan untuk mengembangkan intervensi proses belajar yang benar-benar dibutuhkan oleh masyarakat di berbagai daerah sesuai dengan potensi sumber daya alam dan sumber daya manusia yang mereka miliki.

Garapan kegiatan penelitian bidang pendidikan hendaklah mencakup semua jenis proses belajar, yakni: proses belajar formal, non formal dan informal di tingkat keluarga. 
Agar seluruh lapisan masyarakat memiliki kualitas SDM tinggi, berkepribadian, dewasa (mature) dan bermartabat tidaklah mencukupi hanya dilakukan melalui pengembangan pendidikan formal semata, melainkan perlu diiringi pula oleh pengembangan proses-proses belajar non formal dan informal yang proporsional dan seimbang, sehingga selain prestasi belajar dan kecerdasan yang tinggi dapat tercapai, dapat dikembangkan pula berbagai tatanan sosial (social rules) yang positif, normatif dan manusiawi yang menjadi patokan rambu-rambu setiap orang untuk berperilaku positif.

\section{PUSTAKA ACUAN}

Ausubel, D.P., J.D. Novak and H. Hanesian. Educational Psychology A Cognitive View. $2^{\text {nd }}$ Ed. Hot, Rinehart and Winston Inc. New York, Chicago, Sab Francisco, Toronto, London

Deutsche Gessellschaft Fur Technische Zusammenarbeit (D-GTZ). ZOPP An Introduction To The Method, 1988.

Fukuyama, F. The Great Disruption Human Nature and The Reconstitution Of Social Order.

Simon and Schuster, New York, London, Toronto, Sidney and Singapore, 1999.

Popenoe, D. Sociology. $7^{\text {th }}$ Ed. New Jersey: Prentice Hall, Englewood Cliffs, 1989.

Ruben, B:D: Communication And Human Behavior: $2^{\text {nd }}$ Ed: Macmillan Publishing Company, New York, 1988:

Sen, A. Poverty and Famines An Essay on Entitlement and Deprivation. Glarendon Press, Oxford, 1982.

Thorndike, R.L. The Concept of Over and Under Achievement. New York: Columbia University Teachers College, 1963. 